\title{
In $h$ a $1 \mathrm{t}$.
}

I. Kantorowicz. Goblers Karolinen-Kommentar und seine Nachfolger.

2. Lehmann. Über die Vermögensstrafen des römischen Rechts.

3. Lehmann. Zur Reform des Reichsstrafgesetzbuches. 
